MAGDALENA CHYBOWSKA

DOI : 10.14746/rie.2021.15.8

ORCID: 0000-0003-1196-4764

ELŻBIETA TRAFIAŁEK

Uniwersytet Jana Kochanowskiego w Kielcach

ORCID: 0000-0002-7745-6191

\title{
Modele polityki integracyjnej we współczesnej Europie
}

Kryzys uchodźczy od 2015 roku należy do najpoważniejszych współczesnych problemów Unii Europejskiej (UE) i całej Europy. Rodzi trudne wyzwania tak wobec państw członkowskich Unii, jak i nienależących do Wspólnoty (Norwegia, Wielka Brytania, Islandia, Szwajcaria), stanowiących jednakże dla uciekinierów z różnych regionów świata gwarant azylu, bezpieczeństwa i godnego życia. Bezprecedensowa liczba migrantów przybywających do Europy uwidoczniła słabe strony unijnej polityki migracyjnej i azylowej niezdolnej w istocie do absorpcji tak licznych grup przybywających na Stary Kontynent, najczęściej nielegalnie. Brak skutecznej reakcji polityk UE na ten zwiększony przepływ osób przez Morze Śródziemne wynikał, między innymi, z błędnych założeń dotyczących przyczyn przemieszczania się ludzi, czynników kształtujących ich długoterminowe trajektorie migracji oraz podróży do Europy.

Kwestia nieustannego napływu migrantów i uchodźców nadal dominuje w agendach politycznych na całym świecie i skupia uwagę polityków europejskich. Niedawny kryzys związany z uchodźcami w Europie i dyskusja na temat, jak kryzys przerodził się w problem humanitarny na arenie światowej, jest wciąż żywym zagadnieniem. Powodem takiego stanu rzeczy jest również fakt, że kryzys migracyjny przekształcił się w kwestię bezpieczeństwa w Europie, wpływając tym samym na dynamikę integracji europejskiej. Dla Europy integracja migrantów jest dużym wyzwaniem. Unia skupiła się prawie wyłącznie na doraźnych działaniach, mających na celu powstrzymanie napływu uchodźców i migrantów. Natomiast takie kwestie jak: zaspokojenie potrzeb w zakresie ich przyjmowania i ochrony, pomoc prześladowanym i narażonym na łamanie praw człowieka - potraktowano jako wyzwania mniejszej rangi.

Na szczeblu krajowym i unijnym nie udało się również zaspokoić długoterminowych potrzeb w zakresie integracji uchodźców i migrantów przybywających do Europy. Brak konsensusu politycznego w państwach członkowskich i między nimi oraz naglący charakter kryzysu z pewnością spotęgowały ten stan rzeczy.

Ponadto istniała i nadal istnieje znaczna rozbieżność w zakresie reakcji państw członkowskich na kryzys, szczególnie w przypadku tak trudnej sytuacji osób jak np. uciekających z Syrii. Wiele państw Europy Środkowej i Wschodniej całkowicie odmówiło przyjęcia uchodźców, podczas gdy np. Niemcy i Szwecja początkowo przyjmowały tysiące uciekinierów. Niektóre kraje nie widziały tak dużej liczby osób ubiegających się o azyl w swojej najnowszej historii, podczas gdy w innych fala uchodźcza 
postrzegana była w kategoriach smutnej „powtórki” z kryzysów migracyjnych lat dziewięćdziesiątych poprzedniego wieku.

Kwestie migracyjne mają niebagatelny wpływ na sytuację demograficzną Europy, która podobnie jak inne regiony rozwinięte zmaga się z procesem starzenia się społeczeństw. Ostatnie lata pokazują, że procentowy stosunek osób powyżej sześćdziesiątego piątego roku życia do osób w wieku produkcyjnym stale rośnie. Od 25 do $75 \%$ w drugiej dekadzie XXI wieku, do przewidywanych w 2050 roku proporcji 47 do $53 \%$ (Szabaciuk, 2017, s. 317).

Szansą na odwrócenie wyżej zarysowanych trendów demograficznych jest masowa, kilkusetmilionowa imigracja, tak polityczna, jak i ekonomiczna, ale przy dobrym zarządzaniu kapitałem ludzkim zawsze pomocna w zasilaniu europejskich rynków pracy. Bez niej utrzymanie dotychczasowej liczby ludności, a przede wszystkim odpowiedniego odsetka osób czynnych zawodowo, nie będzie możliwe. Brak wymienności pokoleń oraz niedobory siły roboczej istotnie wpływają na efektywności i konkurencyjność gospodarek europejskich oraz na system ubezpieczeń społecznych w większości państw regionu oparty na solidarności pokoleń.

Istnieje więc wiele narodowych i ponadnarodowych racji, dla których warto zarządzać migracją i tworzyć odpowiednie warunki dla pełnego wykorzystywania potencjału wykształconych, aktywnych, przedsiębiorczych osób, licznych w grupach desperacko opuszczających swoje ojczyzny w poszukiwaniu szeroko rozumianego bezpieczeństwa. W czasach wyzwań demograficznych i ekonomicznych przyczynią się oni bowiem, a w wielu krajach już się przyczyniają, do rozwoju miast i społeczności lokalnych, do zapobiegania skutkom europejskich trendów braku zastępowalności pokoleń w gospodarce, usługach, w strukturach i instytucjach społecznych.

„Społeczeństwa państw Unii Europejskiej, wykazując różnorodność, charakteryzują się równocześnie procesem historycznych modernizacji, zarysowującym się ujednoliceniem wartości, zasad i mechanizmów funkcjonowania. [...] Religia, język, systemy prawne, zwyczaje oraz warunki życia różnią społeczeństwa poszczególnych krajów. Różnorodność ta sprzyja rozwojowi, prowadzi do wzajemnego uczenia się [...]" (Wojtaszczyk, 2006, s. 16). Różne modele integracji proponowane przez państwa członkowskie UE pozwalają więc różnie korzystać z potencjału, jaki niosą za sobą migranci. Poniżej, w oparciu o analizę systemową wybranych pozycji literatury przedmiotu, opisano kluczowe modele polityki integracyjnej. Rozróżniając specyfikę migracji wewnątrzeuropejskich i migracji do Europy, w prezentowanym tekście uwagę skoncentrowano na migracjach spoza europejskiego kręgu cywilizacyjnego.

\section{Model zróżnicowanego wykluczenia}

Stephen Castles w 1995 roku nazwał i opisał model wykluczenia różnicowego, uznawanego głównie w takich krajach (Niemcy i Szwajcaria), które chętnie integrują pracowników migrujących na swoich rynkach pracy, choć zakres tej integracji posiada szereg prawnie regulowanych ograniczeń.

W państwach, w których stosuje się omawiany model integracji, imigranci selektywnie dopuszczani są do tych sfer życia społecznego, w których są potrzebni, jak 
rynek pracy (Janusek-Krysińska, Majewski, 2016, s. 101). Zróżnicowane wykluczenie oznacza więc, że imigranci są włączani w pewne obszary życia społecznego, a odmawia się im dostępu do innych, takich jak obywatelstwo czy uczestnictwo w życiu politycznym. Imigranci stają się mniejszościami etnicznymi, które stanowią część społeczeństwa obywatelskiego jako pracownicy, konsumenci, czy rodzice, ale są wykluczeni z pełnego uczestnictwa w stosunkach gospodarczych, społecznych, kulturalnych i politycznych.

Wykluczenie może nastąpić poprzez mechanizmy prawne, jak odmowa naturalizacji i wyraźne rozróżnienie praw obywateli i osób niebędących obywatelami, bądź poprzez nieformalne praktyki, jak rasizm i dyskryminacja. Imigranci stają się mniejszościami etnicznymi, które są wykluczone z pełnego uczestnictwa w życiu społecznym. Mniejszości te są zwykle w niekorzystnej sytuacji społeczno-ekonomicznej, co sugeruje silny związek między klasą a pochodzeniem etnicznym (Castles, 1995, s. 5).

Model zróżnicowanego wykluczenia charakteryzuje się więc niechęcią społeczeństwa przyjmującego do przyznania praw obywatelskich osobom napływającym do tego społeczeństwa, co niejednokrotnie jest konsekwencją prowadzonej polityki, która utożsamia przynależność obywatelską z przynależnością narodową oraz prawem więzów krwi. Występuje głównie w krajach, w których przynależność do narodu opiera się na przynależności do określonej grupy etnicznej i jest typowy dla krajów Europy Środkowej i Wschodniej, które historycznie stanowiły obszar krzyżowania się najazdów wrogich ludów, migracji, walk granicznych oraz powstania i upadku imperiów. Trudności w tworzeniu państw narodowych doprowadziły do agresywnej i wykluczającej formy nacjonalizmu.

Grecja np. uznaje mit homogeniczności etnicznej związany z silnym nacjonalizmem, a Włochy, w wyniku trudnych doświadczeń walk z regionalizmem - reprezentuje nurt tzw. niepewnego nacjonalizmu, ograniczającego otwartość na przyjmowanie i integrację grup spoza kręgu europejskiego.

Przykładem państwa stosującego klasyczny model zróżnicowanego wykluczenia przez lata były jednak Niemcy i to na tym przykładnie widać, jak brak polityki integracyjnej w stosunku do imigrantów, zwłaszcza w pierwszej fazie osiedlania się, może nieść za sobą negatywne konsekwencje. Współczesna sytuacja migracyjna w Niemczech, zwłaszcza zawiązana $\mathrm{z}$ integracją muzułmanów niemieckich, jest pokłosiem polityki rządu niemieckiego zapoczątkowanej pół wieku temu, a skierowanej do nowoprzybyłych migrantów zarobkowych z Turcji, Iranu, Afganistanu, Maroka i Tunezji. Nierówne traktowanie oraz nieprzyznawanie obywatelstwa niemieckiego, a jedynie pozwolenie na pobyt i pracę na czas określony, i to nierzadko $\mathrm{z}$ ograniczeniem regionalnym, czyli pracę w określonych landach oraz sektorowym, czyli w wybranej gałęzi przemysłu - były praktykami stosowanymi od samego początku XX wieku. Co więcej, przepisy niemieckie utrudniały łączenie rodzin, a niestosowanie się do tych regulacji powodowało odebranie pozwoleń na pracę i pobyt, a w ostateczności i deportację. Unormowania te nie były jednak restrykcyjnie egzekwowane i imigranci licznie, całymi rodzinami, przybywali do Niemiec. Jedynym zauważalnym efektem niemieckiej polityki była postępująca marginalizacja i dyskryminacja tej grupy społecznej (Brzozowski, 2016, s. 57). 


\section{Model asymilacyjny}

Asymilacja imigrantów jest zjawiskiem wielowymiarowym i bardzo złożonym. Początki teorii asymilacji leżą $\mathrm{w}$ spostrzeżeniach i teoriach stymulowanych przez wielką falę imigracji do Stanów Zjednoczonych Ameryki (USA) na przełomie XX i XXI wieku. Wczesna koncepcja asymilacji była opracowana na podstawie badań socjologów z Uniwersytetu w Chicago nad migracją do tego uprzemysłowionego miasta. W odpowiedzi na widoczne zmiany transformacyjne i występujące wokół nich problemy społeczne, założyciele szkoły chicagowskiej opracowali paradygmat asymilacji.

Koncepcja asymilacji identyfikacyjnej socjologa Miltona Gordona wyjaśnia, w jaki sposób grupy mniejszościowe rozwijają poczucie osobowości, co jest ważnym etapem asymilacji imigrantów. Naukowiec ten w latach sześćdziesiątych minionego wieku opracował model teorii asymilacji linearnej. Asymilacja została w niej określona jako stopniowy proces, składający się z kilku etapów następujących po sobie, które kolejno przechodzą imigranci i ich potomkowie. Początkowym etapem, wyróżnionym przez M. Gordona, jest asymilacja kulturowa, czyli tak zwana akulturacja, która polega na nauczeniu się języka kraju przyjmującego oraz na przystosowaniu się do systemu normatywnego i wzorców zachowań społecznych do tych, które obowiązują w kraju pobytu. Asymilacja kulturowa jest niezbędna do wystąpienia asymilacji ekonomicznej, czyli znalezienia pracy zgodnej z oczekiwaniem oraz odpowiadającej finansowo (Maciuszek, 2017, s. 25).

Milton Gordon zidentyfikował siedem podstawowych etapów asymilacji: kulturową, strukturalną, małżeńską, tożsamości, uprzedzeń, dyskryminacji i obywatelską. Kroki te nie są przyczynowo odrębne, lecz opisują różne wymiary tego samego procesu, są więc podprocesami asymilacji. M. Gordon położył duży nacisk na pierwsze dwa etapy, czyli akulturację i asymilację strukturalną. W jego analizie akulturacja może wystąpić bez innych rodzajów asymilacji i może trwać w nieskończoność. Ponadto każdy z podprocesów może odbywać się w różnym stopniu.

Czwartym etapem wielowymiarowego schematu M. Gordona jest asymilacja identyfikacyjna, która ma miejsce, gdy członkowie grupy mniejszościowej, zwykle nowo przybyli imigranci, rozwijają poczucie przynależności do społeczeństwa przyjmującego, nabywając wspomnienia, odczucia i postawy ludzi z tego kręgu kulturowego. Ten etap asymilacji stał się bardziej popularny w późniejszych dyskusjach o asymilacji, zarówno w odniesieniu do potomków europejskich imigrantów, jak i członków nowych grup imigrantów.

Niektórzy badacze uważają asymilację identyfikacyjną M. Gordona za niejednoznaczną. Zarzuty, z jakimi spotyka się ta teoria, dotyczą głównie ,powrotu do, w gruncie rzeczy, liniowego, statycznego przedstawiania asymilacji oraz nierozróżniania pomiędzy asymilacją jednostki i grupy. Ponadto M. Gordon konstruując model, zakładał interakcje zaledwie dwóch grup - przyjmującej i przyjmowanej, nie uwzględniając wariantu grupy przyjmującej i wielu grup przyjmowanych" (Asymilacja - koncepcje przełomu XX $\mathrm{i}$ XXI wieku).

Zasadność i skutki wprowadzenia zasad modelu asymilacji stało się też polem międzynarodowej dyskusji podczas trwania ostatniego, a w istocie nadal trwającego w Europie kryzysu migracyjnego.

Intensywne przepływy migracyjne osiągnęły szczyt w 2015 roku, a kolejne wydarzenia stanowiły przełomowy moment dla Europy i jej sąsiadów, co doprowadziło do 
ponownej definicji wyzwań i szans w zakresie spójności na tym obszarze. Przepływy migracyjne dotyczyły przede wszystkim osób ubiegających się o azyl, a także potencjalnych osób ubiegających się o azyl, uciekających z ogarniętych wojną, tyranią dyktatorską i dotkniętych biedą krajów, takich jak Syria, Irak, czy Afganistan.

Pod presją coraz liczniejszego uchodźstwa humanitarnego, Unia, a zwłaszcza kraje członkowskie odpowiedzialne za ochronę jej granic, stanęły wobec niezmiernie trudnego dylematu: otwarcia czy też zamykania granic przed uciekinierami z całego świata? Problem właściwego wyboru, przyjęcia strategii zgodnej z cywilizacyjnymi standardami utrudniał i nadal utrudnia fakt, iż narastająca fala migracji zwiększyła powszechne obawy o socjalne, ekonomiczne i kulturowe koszty braku adekwatnej do potrzeb polityki integracyjnej na terenie poszczególnych państw narodowych. Jak nigdy wcześniej, polityka migracyjna wygenerowała ogrom wewnątrzeuropejskich nieporozumień.

Obecnie propozycje wprowadzenia lub zaostrzenia ograniczeń imigracyjnych stają się więc coraz bardziej powszechne, a poparcie dla populistycznych prawicowych partii rośnie w wielu zachodnich demokracjach. Jednak na długo przed tymi debatami i obecnym kryzysem uchodźczym wątpliwości różnych grup imigrantów integrujących się ze społeczeństwami przyjmującymi były żywe. Ostatnie lata tylko wzmocniły te tendencje.

Asymilacja jest jedną z polityk migracyjnych, która rozwija programy integracyjne ukierunkowane na zwiększenie uczestnictwa obywatelskiego i politycznego. Kraje, które przestrzegają tych zasad uznają, że akceptacja i jednolitość kultury, języka i zasad kraju goszczącego są koniecznymi kompromisami w celu uzyskania takich samych lub prawie równych korzyści, praw i ochrony przybyszy, jakie gwarantowane są rodzimym obywatelom.

Proces asymilacji może jednak wiązać się również z konfliktami, bowiem w obrębie mechanizmu scalania się kultur można napotkać różne przeszkody oraz bariery wynikające z różnic ideologicznych, politycznych, ekologicznych, społecznych czy kulturowych. „Istnieją różnorodne odstępstwa od jednokierunkowego, uniwersalizującego, transkulturowego modelu asymilacji. Może ona prowadzić także do częściowego jedynie uczestnictwa w nowym systemie społecznym, bez pozbywania się i utraty własnego języka, religii i tożsamości. W każdej grupie kulturowej istnieje zawsze część stawiająca procesom asymilacyjnym opór, który przenosi się na kolejne pokolenia i trwa o wiele dłużej, niż zakładają modele teoretyczne i wymogi polityczne społeczeństwa przyjmującego" (Paleczny, 2019, s. 14).

Europa jest zbiorem państw narodowych, określonych przez historię, język, rasę i kulturę i stara się przyjmować imigrantów z bardzo różnych środowisk kulturowych, rasowych i językowych. Asymilacja jest jednak różna dla różnych grup imigrantów. Kraje członkowskie UE różnią się w niektórych istotnych kwestiach, zwykle dotyczących roli religii, tożsamości i asymilacji kulturowej.

\section{Model wielokulturowy}

Wszyscy ludzie żyją w coraz bardziej heterogenicznym społeczeństwie. Na świecie jest ponad 6 tysięcy różnych języków. Wskaźnik migracji międzynarodowych rośnie 
z każdym rokiem, co powoduje wzrost liczby osób o złożonej tożsamości. Globalizacja, zwiększona migracja, szybsza komunikacja, łatwość transportu i inne siły XXI wieku zwiększyły istniejący skład wielokulturowy oraz różnorodność kulturową w wielu krajach, także w tych, w których wielokulturowość wcześniej po prostu nie istniała.

Różnorodność kulturowa lub wielokulturowość odnosi się do harmonijnego współistnienia i interakcji różnych kultur, przy czym kulturę należy traktować jako zestaw wyróżniających się duchowych, materialnych, intelektualnych i emocjonalnych cech społeczeństwa lub grupy społecznej. Zalicza się do niej, oprócz sztuki i literatury, styl życia, sposoby wspólnego życia, systemy wartości, tradycje i przekonania. Różnorodność kulturowa lub wielokulturowość jest podstawą zbiorowej siły w lokalnych społecznościach, a w konsekwencji i w globalnym społeczeństwie (Joseph, 2018, s. 111). Wielokulturowe podejście do imigracji pojawiło się jako alternatywny model w odpowiedzi na inne dominujące modele. Pomysły wielokulturowości zaczęły się kształtować z inicjatywy UNESCO.

Znaczenie pojęcia wielokulturowości, choć z pozoru jest oczywiste i jednoznaczne, bywa różnie interpretowane i rożnie wcielane w życie. Kraje imigracyjne, takie jak USA czy Kanada, w praktyce podchodzą do zjawiska odmiennie niż kraje europejskie. U podstaw polityki wielokulturowości, przyjmowanej i realizowanej np. przez Kanadę, jest założenie, że obywatel winien wykazywać lojalność względem kanadyjskich struktur państwowych, a akceptacja podstaw kultury dominującej ma być na minimalnym poziomie. $Z$ kolei wielokulturowość proponowana przez USA opiera się na dominacji kultury anglosaskiej (Hryniewicz, 2011, s. 5).

Wielokulturowość, która po raz pierwszy pojawiła się w terminologii amerykańskiej w XIX wieku, jest pojęciem złożonym, trudnym do określenia choćby ze względu na fakt, że używa się go w sensie opisowym, strategicznym i normatywnym. Na poziomie empirycznym oznacza różnorodność demograficzną i kulturową w społeczeństwie. Pojawia się również w dyskursie politycznym i oficjalnych programach zarządzania różnorodnością kulturową. Pomysł ten różni się od monokulturalizmu, czyli obecności jednej kultury w społeczeństwie, oraz od pluralizmu kulturowego.

Koncepcja wielokulturowości nie jest równa pluralizmowi kulturowemu. Niemiecki socjolog Christian Joppke zaznacza, że pluralizm kulturowy różni się od wielokulturowości poprzez dobrowolne członkostwo w grupach i wzajemne uznanie zaangażowanych stron. Jest to bardziej odpowiednie określenie dla tych, których tożsamość narodowa jest zbudowana na różnorodności kulturowej. Stosowną metaforą stosowaną do opisania tego stanu jest „tygiel”, w którym różne grupy ludzi, którzy identyfikują się jako należący do różnych kultur, rozpoznają i akceptują swoje różnice w ramach ich wspólnego życia (Khin, 2019).

Wielokulturowość w krajach imigracyjnych opowiada się za modelem społeczeństwa, w którym heterogeniczność nie jest postrzegana jako państwo przejściowe, ale raczej jako zjawisko trwałe. Koncepcja ta zakłada, że różne grupy w społeczeństwie wpływają na siebie wzajemnie i że razem tworzą przestrzeń narodową. Wszyscy ludzie w społeczeństwie są uważani za obywateli o równych prawach. Podejście wielokulturowe odnosi się do prób integracji różnych kategorii imigrantów w społeczeństwie przyjmującym, dając im jednocześnie możliwość zachowania i rozwoju ich tradycyjnej kultury i stylu życia lub przynajmniej ich istotnych części. 
Dyskurs na temat wielokulturowości rozciąga się od debat w filozofii politycznej na temat tego, czym jest i powinna być wielokulturowość, po publiczne debaty polityków i prawodawców na temat prowadzenia polityki wielokulturowości.

W przeciwieństwie do innych krajów zachodnich, takich jak USA, Kanada i Australia, narody europejskie zaczęły akceptować różnorodność kulturową jako fakt dopiero pod koniec XX wieku. Tendencje te poprzedziła powojenna imigracja i strategie dla poszczególnych krajów, podjęte w celu integracji przybywających cudzoziemców.

Na początku XXI wieku wielokulturowość została poważnie podważona z wielu powodów. Zmieniający się charakter globalnej migracji, nowe formacje społeczne, obejmujące państwa narodowe oraz utrzymująca się słaba sytuacja społeczno-ekonomiczna imigrantów oraz mniejszości etnicznych to jedne z najważniejszych powodów, które wydają się dezaktualizować starsze modele wielokulturowości.

U podstaw odrzucenia wielokulturowości leży też historyczna zmiana. Od czasu ataku na World Trade Center w Nowym Jorku we wrześniu 2001 roku światowe konflikty, które wcześniej ograniczały się do granic starych imperiów, rozprzestrzeniły się na narody samego Zachodu. W konsekwencji, niegdyś odległe różnice dotarły na terytorium europejskie, a kultura, a przede wszystkim religia, stały się polami sporów, na których do dziś toczą się walki o tożsamość. Islam zaczęto postrzegać jako źródło wrogości wobec Zachodu, a populacje islamskie w narodach europejskich pozbawiano niektórych praw obywatelskich. W 2004 roku we Francji zakazano demonstrowania i narzucania religijnych poglądów w sferze publicznej. Był to początek popularności haseł, głoszonych głównie przez ugrupowania europejskich nacjonalistów i populistów, o zagrożeniach wielokulturowości dla państw europejskich.

Miało to konsekwencje dla budowania nowej koncepcji imigracji i integracji. Proces ten wzmocnił fakt, że kultury i społeczności, z których wywodzą się migranci przybywający do Europy, mają bardziej wielopłaszczyznowy charakter niż miało to miejsce jeszcze kilkadziesiąt lat temu. Większość migracji po II wojnie światowej charakteryzowała się większościowym przepływem ludzi na określonych trasach migracyjnych: z Turcji do Niemiec, z Algierii do Francji, czy z Meksyku do USA. Obecnie migranci pochodzą z wielu państw świata i z różnych kontynentów, z różnych obszarów klimatycznych, etnicznych, kulturowych, wyznaniowych. Znacznej rozbudowie uległa też lista krajów docelowych. Co więcej, pozycja społeczna imigrantów również się rozwarstwiła, ponieważ są to zarówno wysoko, jak i nisko wykwalifikowani pracownicy.

\section{Podsumowanie}

Kryzys, który kulminację osiągnął w 2015 roku, uwidocznił niedociągnięcia unijne polityki migracyjnej i wywarł bezprecedensową presję na mechanizmy ustanowione przez Unię w tej dziedzinie. Doprowadziło to również do częściowego zawieszenia w kilku krajach członkowskich umowy o zniesieniu kontroli granicznej i swobodnym przepływie na bazie ustaleń Układu z Schengen z 1985 roku.

W tej sytuacji UE rozpoczęła proces reform swoich głównych narzędzi, w szczególności Wspólnego Europejskiego Systemu Azylowego. Jednak brak silnej woli 
politycznej wśród państw członkowskich spowolnił przebieg procesu. Unia postanowiła znaleźć rozwiązanie poza swoimi wewnętrznymi ustaleniami i główny zakres działania skupiono na działaniach zewnętrznych oraz próbie rozwijania partnerstwa z krajami trzecimi, w celu zablokowania napływających i tranzytowych przepływów migracyjnych z tych obszarów świata.

Nie można zapominać, że bogata Europa zawsze była docelowym kierunkiem migracji dla poszukujących ochrony, bezpieczeństwa, lepszego życia mieszkańców Afryki i Azji, jednak ostatni kryzys związany z falą uchodźstwa przyniósł zjawisku inny wymiar i inne skutki. Humanitarne, ekonomiczne, społeczne, integracyjne, a nawet militarne, gdy w szantażu politycznym wobec Unii białoruski dyktator wykorzystał uchodźców i migrantów jako narzędzie walki w wojnie hybrydowej.

Dobrze zarządzana migracja może sprzyjać rozwojowi zarówno krajów docelowych, jak i pochodzenia. Może też być korzystna dla samych migrantów i ich rodzin. Aby wykorzystać możliwości, przy jednoczesnym zminimalizowaniu wszelkich ryzyk towarzyszących migracji, społeczność globalna musi jednak stale współpracować, ponieważ żaden kraj nie jest w stanie samodzielnie rozwiązać globalnego, narastającego przecież, a nie słabnącego problemu migracji i uchodźstwa. W tym kontekście Wspólnota Europejska od 2015 roku próbuje wypracować wspólnotowe podejście do problemu, w ramach którego będzie można kompleksowo chronić migrantów, uchodźców oraz pomagać krajom partnerskim w usuwaniu pierwotnych przyczyn nielegalnej migracji i popularnego przemytu ludzi. Chociaż wiele inicjatyw zostało już wdrożonych, to brak pełnej jednomyślności w podejściu do kwestii migracji w ramach Wspólnot nie pozwala na całkowite wyeliminowanie problemów związanych z masową migracją i ustaleniem czytelnych, mądrych, apolitycznych reguł prowadzenia tak narodowej, jak i europejskiej polityki integracyjnej.

\section{Bibliografia}

Asymilacja - koncepcje przełomu XX i XXI wieku, https://www.uj.edu.pl/documents/3337228/ c48dc070-94ab-4124-b2a1-104ced4b5c91.

Claire B. J. (2018), The medical Library association guide to developing consumer health collections, Rowman \& Littlefield, Lanham.

Brzozowski J. (2016), Problem asymilacji muzutmańskich imigrantów w Europie, „Zeszyty Naukowe - Akademia Ekonomiczna w Krakowie", nr 699.

Castles S. (1995), Multicultural Citizenship, Department of the Parliamentary Library, Research Paper No. 161995-96, Canberra.

Hryniewicz J. T. (2011), Imigracja i wielokulturowość w warunkach dużego dystansu kulturowego, „Studia Regionalne i Lokalne”, nr 3/45.

Janusek-Krysińska N., Majewski M. (2016), Integracja muzułmanów i kryzys migracyjny jako wyzwania dla niemieckiej i europejskiej dyplomacji, „Pogranicze. Polish Borderlands Studies”, t. 4 , $\mathrm{nr} 1$.

Khin J. (2019), Multiculturalism, EU Centre Background Brief, http://aei.pitt.edu/97423/1/Multiculturalism.pdf.

Maciuszek A. (2017), Latynoscy królowie, nie-żartujacy Dominikańczycy i inni transnarodowi braciszkowie - spoleczne i kulturowe implikacje fenomenu band latynoskich w Hiszpanii, „Ośrodek Badań nad Migracjami”, nr 96/154. 
Paleczny T. (2019), Międzykulturowe typy tożsamości - pomiędzy integracja a asymilacja, , Relacje Międzykulturowe - Intercultural Relations", nr 1/5.

Szabaciuk A. (2017), Migracje z Europy Wschodniej - szanse i zagrożenia dla Unii Europejskiej, „Rocznik Integracji Europejskiej”, nr 11.

Wojtaszczyk K. A. (red.) (2006), Integracja Europejska, Warszawa.

\section{Streszczenie}

Dla Europy integracja migrantów jest dużym wyzwaniem. Zarządzanie migracją stwarza odpowiednie warunki do pełnego wykorzystania potencjału wykształconych, aktywnych i przedsiębiorczych osób, którymi nierzadko są migranci. Różne modele integracji proponowane przez państwa członkowskie UE pozwalają różnie korzystać z potencjału, jaki oni za sobą niosą. W artykule opisano główne modele postaw państw członkowskich wobec migrantów.

Słowa kluczowe: uchodźcy, polityka integracji, wielokulturowość, Unia Europejska

\section{Models of integration policy in contemporary Europe}

\section{Summary}

The integration of refugees is a major challenge for Europe. Migration management creates right conditions for the fully exploit the potential of educated, active and entrepreneurial people, most of whom are immigrants. Various models of integration offered by EU Member States allow for different use of the potential of migrants. The article describes the main models of attitudes of member states towards migrants.

Key words: refugees, policy of integration, multiculturalism, European Union 
